\title{
Formula Pricing and Profit Sharing in Inter-Firm Contracts ${ }^{\dagger}$
}

\author{
Roger D. Blair ${ }^{\mathrm{a}, *}$ and Francine Lafontaine ${ }^{\mathrm{b}}$ \\ ${ }^{a}$ Department of Economics, University of Florida, Gainesville, FL, USA \\ ${ }^{\mathrm{b}}$ William Davidson Professor of Business Economics and Public Policy Ross School of Business, University of Michigan, \\ Ann Arbor, MI, USA
}

\begin{abstract}
Ronald Coase viewed transaction cost minimization as a central goal of contracting and organizational decisions. We discuss how a solution to the traditional successive monopoly problem that has not been discussed in the literature can economize on such costs. Specifically, we show that when we allow for profit sharing between upstream and downstream firms, a simple formula pricing contract can be used to generate the vertically integrated level of profits. This simple contract, empirically, would take the form of the standard linear wholesale price contracts that are ubiquitous in vertical contexts, even those where we might expect successive monopoly to be an issue. We discuss the advantages of the proposed contract from a transaction cost perspective. We also discuss some of its limitations, in particular the likelihood of misrepresentation of costs, and ways in which such misrepresentation might be addressed in the contract. Copyright $\odot 2014$ John Wiley \& Sons, Ltd.
\end{abstract}

\section{INTRODUCTION}

Ronald Coase's introduction of the concept of transaction costs in economics has had a profound impact on the study of numerous economic phenomena. In industrial organization, this impact has manifested itself in an important way in the work of authors who study how firms choose to organize their operations. Much of the literature on this topic, especially the work that followed on important contributions of Williamson (1971) relating transaction costs to asset specificity and hold-up potential, has focused on the question of vertical integration versus market transactions or what

\footnotetext{
*Correspondence to: Department of Economics, University of Florida, Gainesville, Florida 32611, USA. E-mail: rdblair@ufl.edu ${ }^{\dagger}$ This paper relies extensively on earlier work with a great friend, David Kaserman, who left us far too soon. It also relies on joint work by Lafontaine and Slade. For financial support, we thank our institutions, Department of Economics, University of Florida, and Ross School of Business, University of Michigan, respectively.
}

is often called the make-or-buy decision. Moreover, indeed, a vast empirical literature has established the importance of asset specificity and related factors in firms' decisions to produce inputs in house or not. ${ }^{1}$

Interestingly, in this literature, the notion of what constitutes non-integration varies widely across applications (Lafontaine and Slade, 2007). In some cases, the alternative to vertical integration is the kind of arms-length procurement that was envisioned in much of the theoretical literature. However, in many other cases, including the literature on franchise contracts, which we focus on in the succeeding texts, the non-integration option involves detailed, explicit long-term contracts, with duration, renegotiation or other adaptation clauses, spelled out termination circumstances and obligations, and so on. In yet other cases, the contracts are much shorter, in terms of details and duration. Finally, inter-firm relationships often also entail implicit agreements. ${ }^{2}$ 
Ménard (2004, footnote 3) recounts how in a private conversation, Coase once expressed puzzlement at Ménard's use of the term 'strange forms' in the title of a journal article. Ménard (1996) had used this term in his title to describe the kind of organizational forms that lie between the extremes of spot market transactions and vertical integration, organizational forms that Williamson (1991) referred to as hybrids. Coase pointed out to Ménard that these were not really strange, that they might in fact represent the dominant form of doing business. Indeed, Coase had a deep interest in the study of these organizational forms, which he articulated clearly in his Nobel Prize lecture (Coase, 1991, 1992): "The process of contracting needs to be studied in a real world setting. We would then learn of the problems that are encountered and of how they are overcome and we would certainly become aware of the richness of the institutional alternatives among which we have to choose." Many of the activities he engaged in during the later years of his career, including his role in making more contracting data available to researchers and his role as founding member and first president of the International Society of New Institutional Economics (ISNIE), can be explained by his desire to facilitate and encourage empirical work on firms' contracting practices and organizational decisions, or what he referred to as 'the institutional structure of production'. 3 This interest also led him to participate in a conference on franchising organized by Francine Lafontaine and Scott Masten at the University of Michigan in 1994. In private conversations with Lafontaine, Coase mentioned how distribution and franchise contracts were of particular interest to him because they were a context where one could observe and, through thorough analysis, hope to understand the rationale for a good number of inter-firm contracting practices.

In this paper, we examine a traditional contracting problem that is apt to arise in vertical relationships such as franchising, namely the successive monopoly or double marginalization problem. ${ }^{4}$ Traditional contractual solutions to this problem - such as two-part tariffs and resale price maintenance - start from the presumption that the franchisor or upstream firm would obtain all channel profits under vertical integration and thus will aim to extract the same under separation. However, discussions with industry participants suggest that (at least some) franchisors choose to leave above normal returns with their franchisees. ${ }^{5}$ We therefore discuss how, once we allow firms to share profits rather than require that all profits accrue to the upstream firm, a simple linear wholesale pricing contract, that is, the

Copyright () 2014 John Wiley \& Sons, Ltd. type of contract that is typically observed in beer, gasoline, car and other distribution networks, in fact can yield the same level of profits overall - and in some cases even greater level of profits - as can be obtained under vertical integration. ${ }^{6}$ Because the wholesale price that the firms should set is determined via a specific formula in our proposed solution, we refer to our solution as a formula pricing contract. We show that the proposed formula pricing contract has several advantages, from a transaction cost perspective, over the more standard approaches to organize the vertical channel. We also discuss some of its limitations, in particular the likelihood of misrepresentation of costs and its implications, as well as ways in which such misrepresentation might be addressed in the contract.

The paper is organized as follows. In the next section, we discuss the successive monopoly problem and its standard solutions along with their applicability in the context of franchising. In Section 3, we describe the profit-sharing formula pricing contract. In Section 4 , we discuss the performance characteristics of this contract, especially its transaction cost advantages and potential incentive effects. Finally, in Section 5, we discuss how the informational requirements for this contract compare with those of standard solutions. In particular, we show that the parties to the contract will have incentives to misrepresent their costs here as well, and we discuss some contractual mechanisms that can be used to mitigate this problem. We conclude in Section 6.

\section{FRANCHISING AND SUCCESSIVE MONOPOLY}

In traditional franchising, manufacturers of differentiated goods distribute their products through networks of geographically dispersed franchised dealers. ${ }^{7}$ The franchisor's profit from its dealer network flows from the markups that it earns on the products sold to franchisees. In business format franchising, in contrast, franchisees pay a percentage of their revenues in the form of running royalties. In either case, if there is room for only one distributor or one franchisee in a local market, each franchisee will have some exclusivity rights. This means that each franchisee has some degree of monopoly power locally, which, under a linear wholesale price contract and without further controls, gives rise to higher prices, and lower quantities, than the franchisor would prefer. ${ }^{8}$

In the presence of this problem, a manufacturer's profits will improve if it vertically integrates. ${ }^{9}$ Ownership integration across successive stages of production and 
distribution is not without cost, however (Coase, 1937). First, the integrated operation may experience managerial diseconomies as spans of control are extended in the face of asymmetric information and bounded rationality on the part of decision makers (Williamson, 1973). Second, capital costs may increase if lenders and investors are not convinced that sufficient expertise exists for the efficient operation of multiple stages of production simultaneously (Williamson, 1974). Finally, in some industries and jurisdictions, such as car retailing, gasoline sales and alcoholic beverage distribution in several US states, vertical integration may be prohibited. For all these reasons, firms confronted with successive markups may need to resort to contractual alternatives to ownership integration. ${ }^{10}$

The contractual solutions to the successive monopoly problem that have been discussed most in the literature are two-part tariffs, maximum resale prices, and performance standards (minimum output) (refer to, e.g. Blair and Kaserman, 1981, 1983; Blair and Lafontaine, 2005; Belleflamme and Peitz, 2010).

\subsection{Two-Part Tariffs}

Under a two-part tariff, the distributor in a traditional franchise must pay a fixed fee upfront (or per period) in addition to a per unit wholesale price. In order to maximize its profits, the manufacturer would set the per unit wholesale price equal to the marginal cost of production. The distributor would then sell the joint profit maximizing quantity and realize operating profits equal to the vertically integrated profits. The manufacturer then would set the fixed fee equal to that profit. From the manufacturer's perspective, the economic results are economically equivalent to those with ownership integration.

The two-part tariff thus appears to be a straightforward way for a franchisor to extract all of the economic profit and leave the franchisee with no more than a competitive return. There seems to be much to recommend it. However, empirically, the two-part tariff solution has not been adopted by franchisors or, as best we can ascertain, in vertical channels more generally. Indeed, upfront fixed fees are a standard component of business format franchise contracts, but they represent only a small proportion of franchisee payments to franchisors - usually less than $10 \%$ over the duration of the contract. Instead, the bulk of business format franchisor revenues arise from royalties on sales. Given its low level, it seems unlikely that the fixed fee component of these contracts can be a means to extract all the profits that would be left with the franchisee if input prices were set at the manufacturer's marginal cost of production (or acquisition if the inputs are obtained from suppliers). In fact, the level of the fixed fees in business format franchising is explained in the literature rather simply by the franchisor's desire to recoup the cost of setting up and training new franchisees (refer to Blair and Lafontaine, 2005, p. 59 for more on this). ${ }^{11}$ Similarly, to our knowledge, fixed fees are not used extensively in traditional franchising. To the extent that two-part tariffs are used in some cases, the fixed fee appears to be more of a bond to ensure compliance (Caves and Murphy, 1976). ${ }^{12}$

A transaction cost perspective can perhaps shed some light on why two-part tariffs are not used more frequently. In particular, differences in expectations about demand, and differences in attitudes towards risk and in discount factors, will make it difficult to ascertain ex-ante and agree on the right fee to charge, whether a fixed fee is to be charged upfront, or on an ongoing basis. In addition, there is the potential for franchisor ex-post opportunism with a lump-sum franchise fee or any ex-ante agreed upon ongoing fixed fees. For example, once the franchisor has extracted all of the future profits or the franchisee has signed a note promising the same over time, the franchisor's incentives to spend time and effort on maintaining product quality and advertise on behalf of the franchise system are reduced. Additionally, when it comes to high upfront fees, potential franchisees may be wealth constrained. Of course, franchisees could borrow from third parties, and many do. This raises some selection and incentive issues as the franchisee may default on this loan. ${ }^{13}$ Moreover, Klein (1995) posits that contract law and the good faith obligation of the Uniform Commercial Code imposes a duty on a franchisor in all states for good faith and fair dealing (p. 29) and that this obligation makes it difficult to request the kind of large lump-sum fees that would be needed here. Finally, where a manufacturer faces different franchisees with different levels of demand, the fixed fee would have to be specific to each market. All these complications make the fixed upfront fee a less ideal solution to the problem at hand than it might seem to be.

\subsection{Maximum Resale Prices}

The imposition of maximum resale prices is another contractual alternative to vertical integration that has been discussed extensively in the literature. With this strategy, the franchisor sets the maximum resale price equal to the joint profit-maximizing price. Now, the 
franchisee will not be able to impose a second margin or increase the price above the level desired by the franchisor. The franchisor extracts all of the economic profit by setting a wholesale price below the specified resale price by just enough to leave a competitive return for the franchisee. While this would lead, in theory, to the same level of output and consumer welfare as vertical integration (Blair and Kaserman, 1981; Blair and Fesmire, 1986), and in that sense is desirable from a welfare perspective, the Supreme Court decided in its Albrecht v. Herald Company opinion in 1968 that maximum resale price fixing was unlawful per se under the Sherman Act. This decision was severely criticized for nearly 30 years by antitrust law and economics scholars. In its 1997 decision in State Oil Company v. Khan, the Supreme Court now has overturned Albrecht and made maximum resale price fixing subject to the rule of reason. For all intents and purposes, this ruling permits maximum resale price restraints under US antitrust laws. Maximum resale prices thus would appear to provide a safe solution to the successive monopoly problem. However, appearances may be deceiving as some state laws as well as industry-specific laws can still make maximum resale pricing risky for manufacturers. For example, the Florida statute governing motor vehicle licenses (Fla. Stat. §320.60-320.70), in section 320.3209, stipulates that dealer coercion is prohibited, and that " $\mathrm{A}$ manufacturer or distributor may not coerce or attempt to coerce a dealer to: ....(c) Take any action that is unfair or unreasonable to the dealer." In its discussion of repair work, the law further stipulates that a manufacturer shall not require, influence, or attempt to influence a motor vehicle dealer to implement or change the prices for which it sells parts or labor in retail customer repairs. That a car dealer in Florida could use this statute to argue against the imposition of maximum resale prices remains a distinct possibility, in our view. In addition, in contexts where the manufacturer sells in different types of markets, the local franchisee may be better informed about the best pricing policy. Moreover, setting explicitly different wholesale and maximum prices for different markets could lead to disputes with franchisees and potential litigation as well, including suits under the Robinson Patman Act.

\subsection{Performance Standards}

Another familiar solution to the successive monopoly problem involves setting a performance standard, i.e. specifying the quantities that the exclusive distributor

Copyright @ 2014 John Wiley \& Sons, Ltd. must sell. Setting this quantity at the joint profit maximizing level ensures that the distributor will charge the optimal resale price. Combined with the appropriate wholesale price, this contract will allow the manufacturer to obtain all of the economic profit and leave the distributor with only a competitive return. Thus, this contract also seems to be a perfect substitute for vertical integration. Unfortunately, the same state laws that can make maximum resale pricing risky may treat performance standards perhaps even more harshly. In a recent assessment of motor vehicle dealership regulations, Lafontaine and Scott Morton (2010) reported that all but two US states prohibit manufacturers from requiring that dealers accept vehicles they have not ordered. These state laws thus reduce the manufacturer's ability to impose performance standards. Moreover, the same difficulties arise in terms of informational issues related to local demand when it comes to tailoring the performance standards across markets.

None of the solutions to the successive monopoly problem described in the preceding texts contemplate sharing the jointly maximized profits between the manufacturer and the distributor. Under all proposed alternatives, all profit goes to the manufacturer. This may not be surprising in a context where the distributor has no unique attributes. Competition among identical potential distributors would lead to zero economic profits downstream. In the literature, the implicit assumption of homogenous potential distributors indeed leads to the presumption that the manufacturer has all the bargaining power. However, the distributor (franchisee) in the successive monopoly model earns supracompetitive profit in the absence of vertical integration. Consequently, the distributor lacks any incentive to accept an agreement that assigns full profit to the manufacturer (franchisor). In contexts where vertical integration may be difficult to achieve because of legal and other concerns, it becomes particularly important for franchisors to find franchisees and convince them to become part of the manufacturer's exclusive distribution network. Presuming that this can be achieved without leaving some rent with the franchisee is unrealistic. ${ }^{14}$ Moreover, if local demand and costs are not observed with certainty by the manufacturer, a franchisee whose profits are extracted generally via the contract may choose to exert less effort than would be optimal from the manufacturer's perspective. Indeed, the selfenforcement literature on franchising suggests that leaving some profit with the franchisee will ensure that they have reason to put forth effort and generally behave as the franchisor would want (Klein and Leffler, 1981; Klein and Murphy, 1988; Kaufmann and Lafontaine, 
1994; Klein, 1995). The simple framework in the preceding texts, with given demand and costs, does not leave any role for franchisee incentives. However, these are a central theme in the literature on why firms franchise and, in the process, grant some monopoly power to their franchisees (Blair and Lafontaine, 2005). The reason, according to this literature, is that the franchisor can earn greater profits thanks to the greater franchisee effort in generating sales or cutting costs than what they could earn under company ownership, and this, despite the fact that the franchisee might earn some economic profit as well.

In what follows, we explore a contractual arrangement that (1) leads each firm to pursue independent profit maximizing policies that will result in the maximum joint profits; (2) allocates a specified share of these maximized joint profits to each party to the contract; (3) automatically adjusts to differences or changes in final output demand and to changes in production or distribution costs. A contractual arrangement exhibiting these characteristics reduces potential transaction costs in important ways. To make the analysis more comparable to what is done typically in the literature, we abstract from incentive issues in describing the contract and its properties in the succeeding texts. However, we would argue that because it involves profit sharing, the proposed contract also has the advantage of providing much stronger incentives downstream. For both of these reasons, in our view, it provides a better alternative to ownership integration than the standard contractual solutions described in the preceding texts.

\section{FORMULA PRICING AND PROFIT SHARING}

Once one allows for the possibility that the problem might be reformulated to allow for the distributor to earn some profits, it is straightforward to show that successive markups can be avoided with an agreement to share the downstream profits according to some sharing rule, for example, $\alpha$ and $(1-\alpha)$. As described in Belleflamme and Peitz (2010), assuming that the manufacturer sells the product to its franchisees at their marginal cost of production (or purchase price as they are purchased from suppliers), the two firms will achieve the vertically integrated level of profits. As is well known, ex-post transfers then can be used to obtain the desired shares of profits for both parties. However, here again, large lump-sum transfers expost from distributors back to manufacturers or from franchisees to franchisors seem to be the exception

Copyright () 2014 John Wiley \& Sons, Ltd. rather than the rule in franchise and other distribution contracts. Perhaps this is because the manufacturer runs some risk of franchisee or distributor opportunism under this type of arrangement, that is, once the product has been sold to the distributor. More importantly, the manufacturer can avoid this risk by using a formula pricing contract, namely a standard (linear) wholesale pricing contract that implements the desired profit sharing rule directly. Such a contract would work in the following way. The manufacturer's profit $\left(\pi_{P}\right)$ from producing and selling its output at wholesale to a given franchisee is

$\pi_{P}=W(Q) Q-C_{P} Q$

where $Q$ denotes the quantity sold through the franchise, $W(Q)$ is the wholesale price, and $C_{\mathrm{P}}$ is the constant average and marginal cost of production. ${ }^{15}$ The franchisee's profit $\left(\pi_{\mathrm{D}}\right)$ is

$\pi_{D}=P(Q) Q-W(Q) Q-C_{D} Q$

where $P(Q)$ is the retail price, and $C_{D}$ is the constant average and marginal cost of performing the retail distribution function. If production and distribution were conducted by a vertically integrated firm, the profits of the combined operation $\left(\pi_{\mathrm{I}}\right)$ would be

$\pi_{I}=P(Q) Q-C_{P} Q-C_{D} Q$.

Our goal is to devise a linear pricing contract that will do two things: (1) generate combined profits equal to the maximized value of (3), $\pi_{I}^{*}$ and (2) assign shares of these profits equal to $\alpha$ and $1-\alpha$ to the franchisor and the franchisee, respectively, where $0<\alpha<1$. This assignment of profit shares can be accomplished through setting the correct wholesale price. In particular, if we set $\pi_{P}=\alpha \pi_{I}$ and solve for $W$, we obtain

$W=C_{P}+\alpha\left(P-C_{P}-C_{D}\right)$.

In other words, the franchisor would set the wholesale price equal to the cost of production plus the agreed upon share, $\alpha$, times the optimal integrated monopoly markup over all costs. If the franchisor ensures that the wholesale price is set according to (4), it will be assured of realizing $\alpha$ of the profits available to a vertically integrated monopolist. Moreover, by substituting (4) into (2), we can confirm that $\pi_{D}=(1-\alpha) \pi_{I}$. That is, the contract described in (4) automatically assigns a share $(1-\alpha)$ of the integrated profits to the franchisee.

Under the terms of the linear pricing contract (4), each party receives profits that are proportional to the profits that would occur under vertical integration. As a result, independent profit maximization by each 
of the two separate firms leads to combined profits of $\pi_{I} *{ }^{16}$ With such a contract, the franchisor-franchisee contract negotiations are greatly simplified for two reasons: First, as long as both parties have the same information regarding costs and demand, all changes in demand and costs are accommodated automatically in the formula. Second, the contract provides internal incentives for joint profit maximization, that is, it eliminates the output restriction associated with successive monopoly.

Figure 1 illustrates these results for the case of a linear demand curve. A vertically integrated firm would have average (and marginal) cost equal to $C_{D}+C_{P}$. The profit maximizing solution, here again, is to produce $Q_{I}$ units and charge $P_{I}$ per unit at the downstream stage. In the absence of vertical integration, if the franchisor and the franchisee sign a formula price contract wherein the wholesale price is determined by Equation (4), the franchisee's realized marginal cost curve is $\mathrm{MC}$, which is negatively sloped. ${ }^{17}$ In effect, the contract rotates the realized marginal cost curve clockwise around the intersection of MR and the sum of $C_{D}+C_{P}$ (the true marginal costs of production and distribution). The greater the value of $\alpha$ (the franchisor's share of the maximized joint profits), the greater the degree of rotation of the franchisee's realized marginal cost. ${ }^{18}$ It is this alteration of the franchisee's realized marginal cost that circumvents the output restriction associated with successive monopolies. The franchisee is discouraged from reducing its output below $Q_{I}$ because such an output restriction reduces its realized costs by less than the loss in revenue. Equivalently, the franchisee is encouraged to produce the joint profit maximizing output because producing less causes realized marginal cost to rise.

The linear wholesale pricing contract just described achieves the desired level of profit sharing and yields the same total profits as vertical integration does. This seems to provide an appealing solution to the problem of successive monopoly in traditional franchising, where franchisors earn most of their revenues from the sale of their products to franchisees. It also provides a workable solution for other contexts where a manufacturer distributes its products through a reseller or purchases inputs from suppliers and resells them to franchisees.

Royalties that are defined as a percentage of downstream sales, which are the norm in business format franchising contracts, give rise to the same double marginalization problem as in the standard successive monopoly case, however. Thus, royalty on sales contracts cannot yield the level of profits associated with vertical integration (refer to Blair and Lafontaine, 2005, ch. 4). In other words, a business format franchisor that could replace its sales royalties with input markups might do well to do so. ${ }^{19}$ Indeed, Chicken Delight, as a business format franchisor,

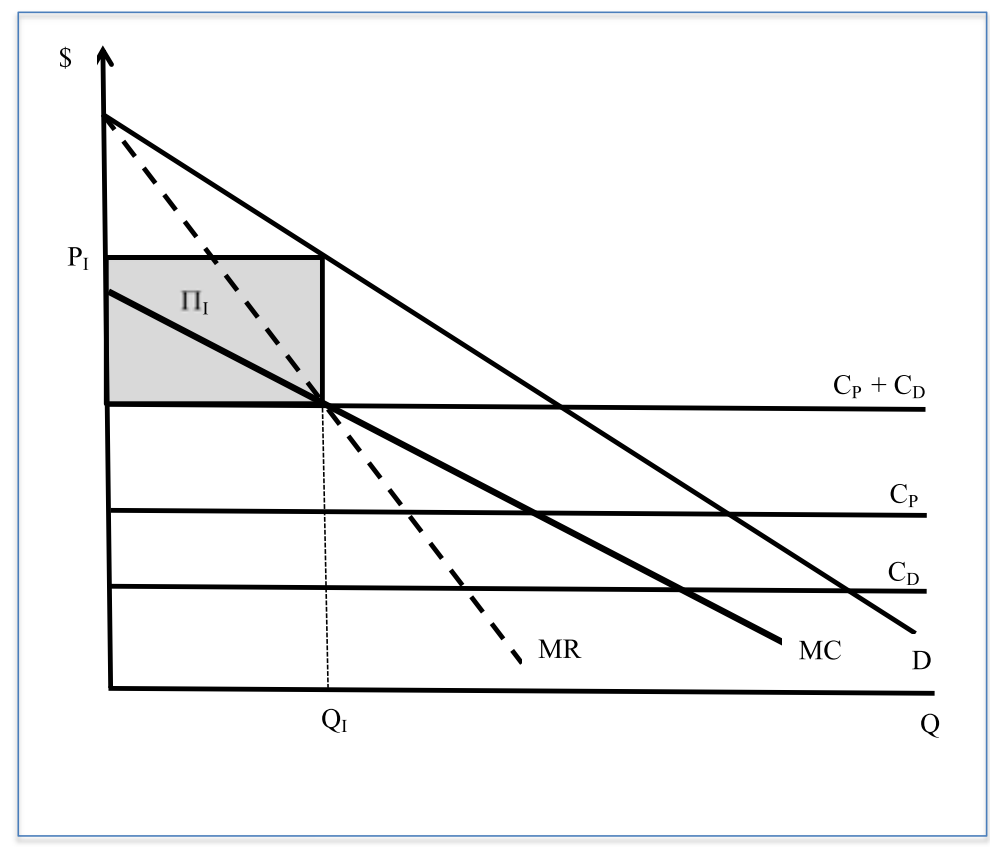

Figure 1. An illustration. 
charged no royalties on sales and obtained all its revenues from the sale of inputs to its franchisees, inputs that the franchisor, in turn, procured from the market. Its franchisees were precluded from buying these items from other sources. Siegel, one of its franchisees, sued Chicken Delight, complaining that he was being overcharged for these products. The court found that even though Chicken Delight had no separate charge for using its franchise system, the franchise itself served as a tying product while the other inputs the franchisee was required to buy were tied products. ${ }^{20}$ This decision, in effect, made it impossible for business format franchisors to use the type of linear wholesale or formula pricing that we have shown would avoid the double margin problem. $^{21}$

\section{PERFORMANCE CHARACTERISTICS OF THE FORMULA PRICING CONTRACT}

In this section, we explore the performance characteristics of the formula price contract, starting with the advantages of this contract from a transaction cost perspective. We also explore specific incentive advantages of this type of contract.

In terms of minimizing transaction costs, the formula price contract exhibits three desirable performance characteristics.

First, it facilitates the negotiation process by focusing attention on a single parameter, $\alpha$. With the manufacturer and distributor each automatically driven to produce the joint profit maximizing quantity, there is no need to specify in advance the price and output of the intermediate product. The parties to the contract need only settle on mutually agreeable shares of the resulting maximized profit to define what will be the pricing schedule (as a function of costs), thereby keeping down the transaction costs associated with the contracting process.

Second, the formula price contract reduces transaction costs by economizing on the information needed for contract specification. Again, because of the incentive structure that automatically leads the two firms to produce the joint profit maximizing output, and contrary to most other contractual solutions, the parties to the contract do not require information on final product demand in order to specify the terms of the contract. That is, the share, and thus a central aspect of the contract, can be negotiated prior to the revelation of information regarding $P(Q)$ and costs. As a result, the same share agreement also can be used across locations facing somewhat different demands and costs.

Third, once the formula price contract is in effect, changes in final output demand or in costs at either stage will be reflected appropriately in the new optimal prices and outputs fostered by the contract. That is, the contract will automatically accommodate changes in $P(Q), C_{D}$, or $C_{P}$, encouraging the parties to the contract to adjust to the new joint profit maximizing solution. Moreover, the firms' realized shares of the new optimal profit will remain at the agreed upon values of $\alpha$ and $1-\alpha$. No renegotiation is required as a result of dynamic changes in final product demand or costs. $^{22}$ In this respect, the formula price contract appears to operate in a fashion that is identical to the ownership integration alternative and less costly than the other contractual alternatives, all of which require setting new terms, be they prices, quantities, or fixed upfront fees in reaction to changes in market conditions.

Finally, the formula pricing contract leaves some profit, or rent, with franchisees. This, in turn, gives franchisees incentives to work hard and not free-ride on the goodwill associated with the brand. Specifically, franchisees who earn above normal returns in the context of their franchise relationship will work hard for fear of having the franchisor find that they are not performing their duties properly, which could lead to termination (refer to, for example Blair and Lafontaine, 2005, ch. 10, for a discussion of self-enforcement in franchising). In the previous discussion, we have assumed that costs and demand become common knowledge at some point after the contracts are set, and are unaffected by the form of the contract. However, the franchise literature is replete with the notion that franchisors use franchising because franchisees put forth more effort than hired managers do. Presumably, the increased effort by the franchisee yields some tangible benefits, either in the form of increased demand locally or lower costs of distribution relative to what the franchisor could obtain under vertical integration. In this case, the local operations can yield greater profits to be shared between the franchisor and the franchisee than would be possible under vertical integration. Thus, even while leaving some of those profits downstream, the franchisor could be better off in the end with the formula pricing contract than under vertical integration. ${ }^{23}$ 


\section{INCENTIVES FOR STRATEGIC MISREPRESENTATION}

While we have shown that the formula pricing contract has a number of desirable properties, we can see from Equation (4) that the optimal wholesale price in this contract is a function of the unit cost of production, $C_{P}$, and the unit cost of performing the distribution function, $C_{D}$. This raises the issue of whether the parties to the contract will have an incentive to misrepresent their costs once the terms of the formula price contract have been set. In other words, does the formula price contract present the parties with postcontractual incentives to behave opportunistically? Not surprisingly, the answer to this question is yes. Thus, the formula price contract involves some potential costs of auditing, thereby raising the transaction costs of employing these contracts. We would argue, however, that the same misrepresentation risks exist under the other contractual alternatives, and perhaps even under vertical integration if the manager of the distribution arm, for example, is paid based on downstream revenues or profits.

To examine the incentive for strategic misrepresentation of costs under the formula price contract, we focus on each firm's profit function at the truthful solution. We then ask whether the firm's profits may be increased by over-representing its costs to its contract partner. We first examine misrepresentation incentives on the part of the franchisor. For simplicity, we assume constant average costs.

From Equation (4), if the franchisor's true average costs are $C_{P}$, but the firm claims they are $C_{P}+\delta$, where $\delta>0$, the wholesale price per the terms of the contract will be

$$
W=\alpha\left(P-C_{D}\right)+(1-\alpha)\left(C_{P}+\delta\right) .
$$

Note that the optimal retail price, $P$, also will be affected by the level of misrepresentation, $\delta$. Substituting (5) into Equation (1), the franchisor's profits with misrepresentation are

$$
\begin{aligned}
\pi_{P} & =\left(\alpha\left(P-C_{D}\right)+(1-\alpha)\left(C_{P}+\delta\right)\right) Q-C_{P} Q \\
& =\alpha\left(P Q-C_{D} Q-\left(C_{P}+\delta\right) Q\right)+\delta Q \\
& =\alpha \pi_{I}(\delta)+\delta Q(\delta) .
\end{aligned}
$$

In other words, the franchisor's profits are its share of the new joint profit, $\pi_{I}(\delta)$, which is a function of the level of misrepresentation, plus the misrepresentation on cost times the new output, which also depends on $\delta$.
Whether an incentive for misrepresentation exists depends upon the sign of $d \pi_{p} / d \delta$ evaluated at $\delta=0$. That is, at the truthful solution, an incentive for misrepresentation exists if the franchisor can increase its profits by engaging in some misrepresentation. From (6),

$\frac{d \pi_{P}}{d \delta}=\alpha \frac{d \pi_{I}(\delta)}{d \delta}+\delta \frac{d Q}{d \delta}+Q$

The second term on the right-hand side is clearly zero when $\delta$ is zero. Thus $\frac{d \pi_{P}}{d \delta}>0$ if

$Q>-\alpha \frac{d \pi_{I}(\delta)}{d \delta}$

From Equation (3), integrated profits with misrepresentation, ${ }^{24}$ or, equivalently, the amount of profit to be shared, will be

$\pi_{I}(\delta)=P(Q(\delta)) Q(\delta)-C_{D} Q(\delta)-\left(C_{P}+\delta\right) Q(\delta)$.

Therefore,

$$
\begin{aligned}
\frac{d \pi_{I}}{d \delta} & =P \frac{d Q}{d \delta}+Q \frac{d P}{d Q} \frac{d Q}{d \delta}-C_{D} \frac{d Q}{d \delta}-C_{P} \frac{d Q}{d \delta}-\delta \frac{d Q}{d \delta}-Q \\
& =\left[P+Q \frac{d P}{d Q}-\left(C_{D}+C_{P}\right)\right] \frac{d Q}{d \delta}-Q
\end{aligned}
$$

At $\delta=0$, the bracketed term equals zero: This is the first-order condition for profit maximization when there is no misrepresentation. Thus, at $\delta=0$,

$\frac{d \pi_{I}}{d \delta}=-Q$

Substituting (9) into (8) yields $Q>\alpha Q$, which indicates that $\frac{d \pi_{P}}{d \delta}>0$ at $\delta=0$. That is, the franchisor has an incentive to misrepresent its costs for any $0<\alpha<1$.

We can gain further insight into the intensity of misrepresentation by setting Equation (7) equal to zero and solving for the optimal level of misrepresentation:

$\delta^{*}=-\left(\alpha \frac{d \pi_{I}(\delta)}{d \delta}+Q\right) /\left(\frac{d Q}{d \delta}\right)$.

Differentiating this expression with respect to $\alpha$, we find

$\frac{d \delta^{*}}{d \alpha}=-\left(\frac{d \pi_{I}(\delta)}{d \delta}\right) /\left(\frac{d Q}{d \delta}\right)$

which is negative given that both $\pi_{I}$ and $Q$ are decreasing in the amount of misrepresentation. Thus, not 
surprisingly, the upstream firm will have less incentive to misrepresent its cost the larger its share of the joint profits.

The analysis in the preceding texts applies to the franchisor's incentive to misrepresent its costs. A completely analogous incentive exists on the part of the franchisee. Not surprisingly, however, the downstream firm will have a greater incentive to misrepresent its cost the larger the value of $\alpha$.

An interesting issue, then, involves the contractual and non-contractual responses to these incentives for strategic behavior. A thorough investigation of this issue is beyond the scope of this paper, but we offer some preliminary observations. First, because both parties to the contract may engage in misrepresentation, there will be a clear incentive for both to incorporate some sort of policing mechanism in the contract. For example, the contract could provide for regular audits of both the franchisor and the franchisee. In the event that the audit uncovers misrepresentation, there are two possible sanctions: (1) contract damages and (2) termination of the franchise relationship. If the opportunistic misrepresentation of cost constitutes a breach of contract, then the victim of the breach will be entitled to contract damages, which should reflect the lost profits. In this case, the lost profits will be equal to the difference between the jointly maximized profits and the profits impaired by the misrepresentation times the victim's share (either $\alpha$ or $(1-\alpha)$ as the case may be).

Alternatively, misrepresentation may give rise to termination of the franchise relationship. In that event, both parties suffer a loss of profit in the future. For the threat of termination to deter misrepresentation, the present value of the profits for the remainder of the franchise contract must exceed the increase in profits that misrepresentation affords. That is, misrepresentation will be deterred if

$$
\sum_{t=1}^{T} \pi_{t} /(1+i)^{t}>\Delta \pi
$$

where $\Delta \pi$ is the added profit that misrepresentation yields, $\pi_{t}$ is the yearly profit that flows from the franchise operation, and $T$ is the number of years left on the contract. ${ }^{25}$ Deterrence increases with increases in $T$. It falls with increases in $i$. It increases with increases in $\pi_{t}$. It falls with increases in $\Delta \pi$.

Finally, in using the formula pricing contract, noncontractual enforcement mechanisms may be adopted. For example, where multiple geographic markets exist at one or both stages of production, it may be possible for the firm to partially vertically integrate to obtain a yardstick against which to compare its contract partner's costs. Such partial integration for information purposes may provide one explanation for the phenomenon of dual distribution, which is an important phenomenon empirically in both traditional and business format franchise systems.

\section{CONCLUSION}

Our goal with this paper was to suggest an explanation for the prevalence of simple linear wholesale price contracts, a type of contract that is ubiquitous in vertical relationships, including some where the successive monopoly problem is apt to be severe, namely both traditional and business format franchising. Assuming that the wholesale price is set according to the correct formula, franchisors and franchisees could share profits via such a contract and, in the process, also potentially solve the successive monopoly problem. Of course, the extent to which formula pricing as described herein explains the ubiquity of simple linear wholesale pricing contracts is difficult to ascertain empirically as the profit sharing aspect might be a rather implicit component of the agreement. However, conversations with franchisors and franchisees, and some early descriptions of the process by which firms set the fees in these contracts, suggest that franchisors aim to set these so as to achieve a certain level of profit sharing with franchisees.

As emphasized by Coase in his Nobel Lecture (1991, 1992), in the end, the choice between alternative modes of organization should turn on a comparison of the transaction costs associated with each option, including the costs of negotiation, the cost of adaptation, the incentive cost, and the cost of misrepresentation or auditing. We have demonstrated how a formula pricing agreement indeed would solve the successive monopoly problem when information about costs and demand levels is available, and there are no effort effects. Moreover, we have discussed how, by leaving rent or profits downstream, franchisors may achieve even greater profits under the formula pricing contract than under vertical integration. Finally, we have described how the formula pricing contract exhibits several transaction cost economizing properties. We conclude that firms confronted with the problem of monopoly power at successive stages of production have an attractive alternative to vertical ownership integration or standard contractual solutions if they agree to negotiate profit shares. The 
existence of this approach, in turn, may explain why simple linear wholesale contracts remain, in practice, so prevalent.

\section{ENDNOTES}

1. For reviews of this large literature, refer to, e.g. Lafontaine and Slade (2007) and Joskow (2010).

2. Refer to Lafontaine and Slade (2013) for a review of the empirical literature on vertical inter-firm contracts, which describes some of the different types and features of such contracts.

3. In particular, Coase $(1991,1992)$ describes his role in organizing a conference for this purpose, as well as his involvement with the creation of the Center for the Study of Contracts and the Structure of Enterprise at the Business School of the University of Pittsburgh. Refer also to http://cori.missouri.edu/ for information concerning his support for the Contracting \& Organizations Research Institute at the University of Missouri. Finally, for more on ISNIE, refer to http://www.isnie. org/about.html.

4. Refer to Spengler (1950) and Machlup and Taber (1960) for early treatments of the successive monopoly problem.

5. Refer to Kaufmann and Lafontaine (1994) for related evidence. Similarly, David Kaserman was led to study formula pricing contracts that involved profit sharing after he heard of such contracts being used in practice.

6. Refer also to Blair and Kaserman (1987) for an examination of price contracts as a means of dealing with the bilateral monopoly problem.

7. Traditional franchising deals with product distribution. In contrast, business format franchising involves the transfer from franchisor to franchisee of a method of doing business, including sourcing of inputs and operating procedures.

8. Refer to in particular Blair and Lafontaine (2005) for a discussion of double marginalization arising from the imposition of royalties on sales in business format franchising.

9. Refer to, e.g. Blair and Kaserman (1983) for a simple demonstration.

10. Refer to in particular Mathewson and Winter (1984) on the equivalence of (combinations of) vertical restraints and vertical integration.

11. The fact that some franchisors reduce franchise fees for additional outlets opened by the same franchisee is further evidence in favor of this explanation (Blair and Lafontaine, 2005, p. 57).

12. Rent paid by gasoline dealership operators to oil companies, however, could constitute a form of fixed fee, i.e. the rent may be above normal real estate rental rates.

13. Refer also to Fan et al. (2014) on incentive issues that lead franchisors to request that franchisees personally finance a significant portion of the initial investment required for the franchise.

14. Indeed, franchisors typically have a 'franchise sales department' and they expend significant amounts of resources to recruit potential franchisees.
15. We assume constant average and marginal costs of production and distribution of the franchisors' products, which we believe are reasonable assumptions for beer, cars, gasoline and soft drinks, for example. This allows us to simplify the analyses and, in particular, simplify the extension to the multi-market case, which we think is of particular interest in these types of industries.

16. This can be seen by substituting (4) into (1) and (2) and examining the first-order conditions for each party.

17. In the linear case that we illustrate, it can be shown that the vertical intercept of the downstream firm's realized marginal cost curve will be greater than, equal to, or less than $P_{I}$ as $\alpha$ is greater than, equal to, or less than 0.5. Moreover, the level of profits that accrue to the franchisor is the area above $C_{D}+C_{P}$ but below the realized marginal cost curve.

18. If $\alpha=1$, then the realized marginal cost coincides with MR and a unique solution does not exist at the downstream stage.

19. Refer also to Klein and Saft (1985) on the policing advantages of input tying, whereby the franchisor can monitor the use and quality of inputs used by franchisees.

20. Refer to Siegel v. Chicken Delight, 1971.

21. As noted by Maness (1996) and Belleflamme and Peitz (2010), revenue sharing likely is preferred to profit sharing because of the problem with measuring costs downstream, which we discuss briefly in the succeeding texts. Moreover, if downstream costs are large, as will be the case if production occurs mostly downstream (e.g. fast-food), sales royalties have the advantage that they give strong incentives to franchisees to keep costs low. We revisit this also briefly in the succeeding texts.

22. This is not to say that renegotiation of the profit shares themselves will never be necessary but that fluctuations in cost and demand conditions, which may occur frequently, do not require any such renegotiation.

23. Refer to Shelton (1967) and Krueger (1991) for evidence that costs are lower under franchisee management. Similarly, in a private conversation with one of the authors, a franchisor mentioned that he could never have brought himself to pay a salary commensurate with the level of profit that his franchisee was earning. However, he never considered buying back his franchisee's outlets because he could not make as much money under corporate ownership as he was getting in royalties given this franchisee's skills and effort. Another franchisor put it simply: "You can't pay a manager enough to make them get up in the morning and do what the franchisee will do!" (David McKinnon, then Chairman and CEO, Service Brands International, during a panel discussion organized on September 13, 2002 at the University of Michigan Business School.)

24. Although one would not expect a vertically integrated firm to misrepresent its cost to itself, a division manager might misrepresent its costs to his superiors if he stands to gain from doing so.

25. For more on this, refer to Klein and Leffler (1981) and Klein and Murphy (1988). 


\section{REFERENCES}

Albrecht v. Herald Co. 390 U.S. 145, 1968.

Belleflamme P, Peitz M. 2010. Industrial Organization: Markets and Strategies. Cambridge U. Press: Cambridge, UK.

Blair RD, Fesmire JM. 1986. Maximum Price Fixing and the Goals of Antitrust. Syracuse Law Review 37: 43-77.

Blair RD, Kaserman DL. 1981. The Albrecht Rule and Consumer Welfare: An Economic Analysis. University of Florida Law Review 33: 461-484.

Blair RD, Kaserman DL. 1983. Law and Economics of Vertical Integration and Control. Academic Press: New York.

Blair RD, Kaserman DL. 1987. A Note on Bilateral Monopoly and Formula Price Contracts. American Economic Review 77: 460-463.

Blair RD, Lafontaine F. 2005. The Economics of Franchising, Cambridge University Press: New York.

Caves RE, Murphy WF II. 1976. Franchising: Firms, Markets, and Intangible Assets. Southern Economic Journal 42: $572-586$

Coase RH. 1937. The Nature of the Firm. Economica 4: 386-405.

Coase RH. 1991, 1992. The Institutional Structure of Production. Alfred Nobel Memorial Prize Lecture in Economic Sciences, Nobel Foundation, reprinted in: American Economic Review 82: 713-719.

Fan Y, Kuhn K-U, Lafontaine F. 2014. Financial Constraints and Moral Hazard: The Case of Franchising. Available at http://www-personal.umich.edu/ yingfan/franchsing_Fan_ Kuhn_Lafontaine.pdf [February 15, 2014].

Joskow P. 2010. Vertical Integration, Symposium in Honor of Oliver Williamson. The Antitrust Bulletin 35: 545-586.

Kaufmann PJ, Lafontaine F. 1994. Costs of Control: The Source of Economic Rents for McDonald's Franchisees. Journal of Law and Economics 37: 417-454.

Klein B. 1995. The Economics of Franchise Contracts. Journal of Corporate Finance 2: 9-37.

Klein B, Leffler KB. 1981. The Role of Market Forces in Assuring Contractual Performance. Journal of Political Economy 89: 615-641.

Klein B, Murphy KM. 1988. Vertical Restraints as Contract Enforcement Mechanisms. Journal of Law and Economics 31: 265-297.

Klein B, Saft LF. 1985. The Law and Economics of Franchise Tying Contracts. Journal of Law and Economics 28: $503-526$.

Krueger A. 1991. Ownership, Agency and Wages: An Examination of the Fast Food Industry. Quarterly Journal of Economics 23: 263-283.
Lafontaine F, Scott Morton F. 2010. Markets: State Franchise Laws, Dealer Terminations, and the Auto Crisis. Journal of Economic Perspectives 24: 233-250.

Lafontaine F, Slade ME. 2007. Vertical Integration and Firm Boundaries: The Evidence. Journal of Economic Literature 45: 629-685.

Lafontaine F, Slade ME. 2008. Empirical Assessment of Exclusive Contracts (with Margaret Slade). In Handbook of Antitrust Economics, P Buccirossi (ed). MIT Press: Cambridge.

Lafontaine F, Slade ME. 2013. Inter-Firm Contracts: The Evidence (with Margaret Slade). In Handbook of Organizational Economics, Gibbons R, Roberts J (eds). Princeton University Press: Princeton, NJ 958-1013.

Machlup F, Taber M. 1960. Bilateral Monopoly, Successive Monopoly, and Vertical Integration. Economica 27: 101-119.

Maness R. 1996. Incomplete Contracts and the Choice Between Vertical Integration and Franchising. Journal of Economic Behavior and Organization 31: 101-115.

Mathewson F, Winter RA. 1984. An Economic Theory of Vertical Restraints. Rand Journal of Economics 15: 27-38.

Ménard C. 1996. On Clusters, Hybrids and Other Strange Forms: The Case of the French Poultry Industry. Journal of Institutional and Theoretical Economics 152: 154-183.

Ménard C. 2004. The Economics of Hybrid Organizations. Journal of Institutional and Theoretical Economics 160: $1-32$.

Siegel $v$. Chicken Delight. 448 F. 2d 43 (9th Cir. 1971).

Shelton J. 1967. Allocative Efficiency vs. 'X-Efficiency': Comment. American Economic Review 57: 1252-1258.

Spengler JJ. 1950. Vertical Integration and Antitrust Policy. Journal of Political Economy 58: 347-352.

State Oil Company vm Khan 118 S. Ct. 275 (1997).

Williamson OE. 1971. The Vertical Integration of Production: Market Failure Considerations. American Economic Review 61: 112-123.

Williamson OE. 1973. Markets and Hierarchies: Some Elementary Considerations. American Economic Review 63: 316-325.

Williamson OE. 1974. The Economics of Antitrust: Transaction Cost Considerations. University of Pennsylvania Law Review 122: 1439-1496.

Williamson OE. 1991. Comparative Economic Organization: The Analysis of Discrete Structural Alternatives. Administrative Science Quarterly 36: 269-296. 